\title{
Mapping the Persistence and Evolution of the Quincunx
}

\section{Fabio Colonnese ${ }^{1}$ (D)}

Accepted: 20 September 2020 / Published online: 8 October 2020

(c) The Author(s) 2020

\begin{abstract}
The quincunx is a pattern that passes through different ages and cultures of Western world. It spread in the Byzantine era; it flourishes during the Renaissance, either in combination or as an alternative to the Vitruvian proportioning criteria; it suffers from a process of mathematization in the eighteenth century; it arrives at the twentieth century in the form of the so-called "nine-square grid problem" and is further re-evaluated in its historical prospective at the end of the century, in the Post-modern context. This article provides a mapping of its diffusion and inquires its development and evolution through the centuries.
\end{abstract}

Keywords Quincunx · Architectural plan · Square patterns

\section{Introduction}

The game of tris or tic-tac-toe is widespread throughout the world. In ancient Rome, where people used to practice it onto the marble steps of theatres and arenas, it was named terni lapilli, for it consists in sequencing three pebbles (lapilli in Latin) inside a square grid of nine boxes. In the paper version, still practiced today by children, each of two players alternatively marks either a circle or a St Andrew's cross in one of the nine boxes, trying to put three in a sequence. The result is that the grid, filled with crosses and circles, ends up resembling the plan of a quincunx church, a quadrangular building featuring an internal division in nine cells vaulted with domes or cross-vaults (Fig. 1). As in the game, in which the grid is quickly drawn before positioning the marks, modern architects have often adopted a similar approach and scheme as a sort of opening move in order to get a new project started. Obviously, its development is intertwined with the gradual spread of the grid as a drawing and design system, whose origins are here associated with the quincunx, a pattern that passed

Fabio Colonnese

fabio.colonnese@uniroma1.it

1 Department of History, Drawing and Restoration of Architecture, Sapienza University, Rome, Italy 
Fig. 1 The game of tris or tictac-toe

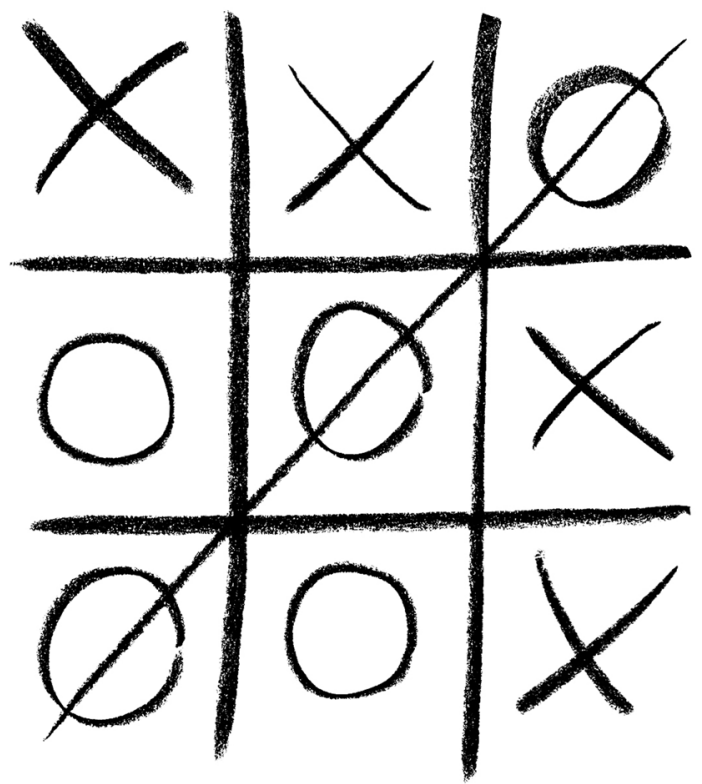

through different ages and cultures of Western world. It spread in the Byzantine era; flourished during the Renaissance, migrating from religious to residential architecture; it suffered from a process of "mathematization" in the eighteenth century; it arrived at the twentieth century as a concrete-oriented layout and was further re-evaluated in its historical perspective in the Postmodern context.

As this article will demonstrate, over the centuries the quincunx evolved along two intertwined paths, fueled by both its semantic, intertextual power and its geometric, combinatory potential. The former gradually provided new buildings with a direct reference to antiquity, to the centricity of Renaissance temples, to Italian villas (and culture) and, in the twentieth century, to a general idea of monumentality to elaborate, contest or distort; the latter offered designers a simple trigger to start designing and an opportunity to explore centricity vs. serialism, to apply mathematical ratios, and to develop rational, serial and flexible designs for public and private buildings.

After the introduction of the quincunx as an ancient religious typology and its revival in the fifteenth century as both a reference to antiquity and an adaptable layout to sacralize villas, I will first describe the seventeenth-century interpretation of the quincunx as a rational, mathematical $3 \times 3$ grid eventually embodying the idea of the Italian pleasure house; and then inquire into its relationship with the so-called "nine-square grid problem" and the twentiethcentury quincunx applications as a tool of criticism and design. 


\section{The Quincunx: History and Fifteenth-Century Revival}

The quinconce was an ancient Roman bronze coin with five points on one of its faces arranged as on a modern die: four in the corners and one in the middle. In architecture, the Latin term quincunx is instead used to label a building with four pillars (tetrastylum) dividing a square plan in nine parts, and five domes as disposed as the points on the coin. Originally this term mainly described buildings first of the Armenian, and then Byzantine and Arab traditions (Krautheimer 1965) but related designs feature martyrium and tetrastylum atrium in Roman religious and thermal buildings (Fig. 2).

According to Krautheimer:

its core, the naos, is small, steep and enclosed in the outline of a square, and composed by nine elements: a tall centre bay, resting on four supports, either columns or piers; a high, well-lit drum of a dome rising as a rule from pendentives; subordinate to it, four short barrel-vaulted cross arms expanding in the main axes; lower, in the diagonal axes, four corner bays, groin-vaulted, barrel-vaulted, or domed. Jointly these corner bays, sometimes surmounted on the exterior by the higher drums of sham domes, and the taller main dome, form the five spots of a quincunx (1965: 245) (Fig. 2).

While acquiring iconographic connotations of the Holy Land and the Celestial Jerusalem (Cardamone 2000), the quincunx presented several formal variations. The plan could be square or rectangular; could include a cross of cells covered with vaulted ceilings; could do without the five domes and instead have one or three apses and an external narthex, as well. In practice, the term quincunx came to identify different buildings or only parts of them sharing the idea of centric space and showing a plan divided in nine areas by four supports.

The examples available in the mid-sixteenth century, a time that witnessed a sort of revival of the quincunx in many new religious buildings, show a remarkable oscillation between formal characterization and generalization. The sacellum of S. Satiro in Milan, whose Byzantine matrix aspires to a pyramidal composition through a peculiar use of the vaults, occupies one extreme of this oscillation field while the other is ideally marked by the church of S. Maria in Portico in Fontegiusta, which presents a generic, flexible space, related to the a-directional spatiality of the hallen-kirche typology (Fig. 3).

While in the Venetian area the quincunx revival of fifteenth and sixteenth centuries can be explained by both the strict relationship with the Byzantine culture and the persisting antiquarian reference to the main body of the church of S. Marco (Cardamone 2000), elsewhere this revival is quite difficult to understand. Surely, the presence of quincunx schemes in both the Cosmatesque mosaic floors and antique monuments described in Latin texts, such as Pliny's Tomb of Porsenna (Colonnese 2015), contributed to the consideration of it as an important geometric pattern. A central role in bridging this antiquarian typology 


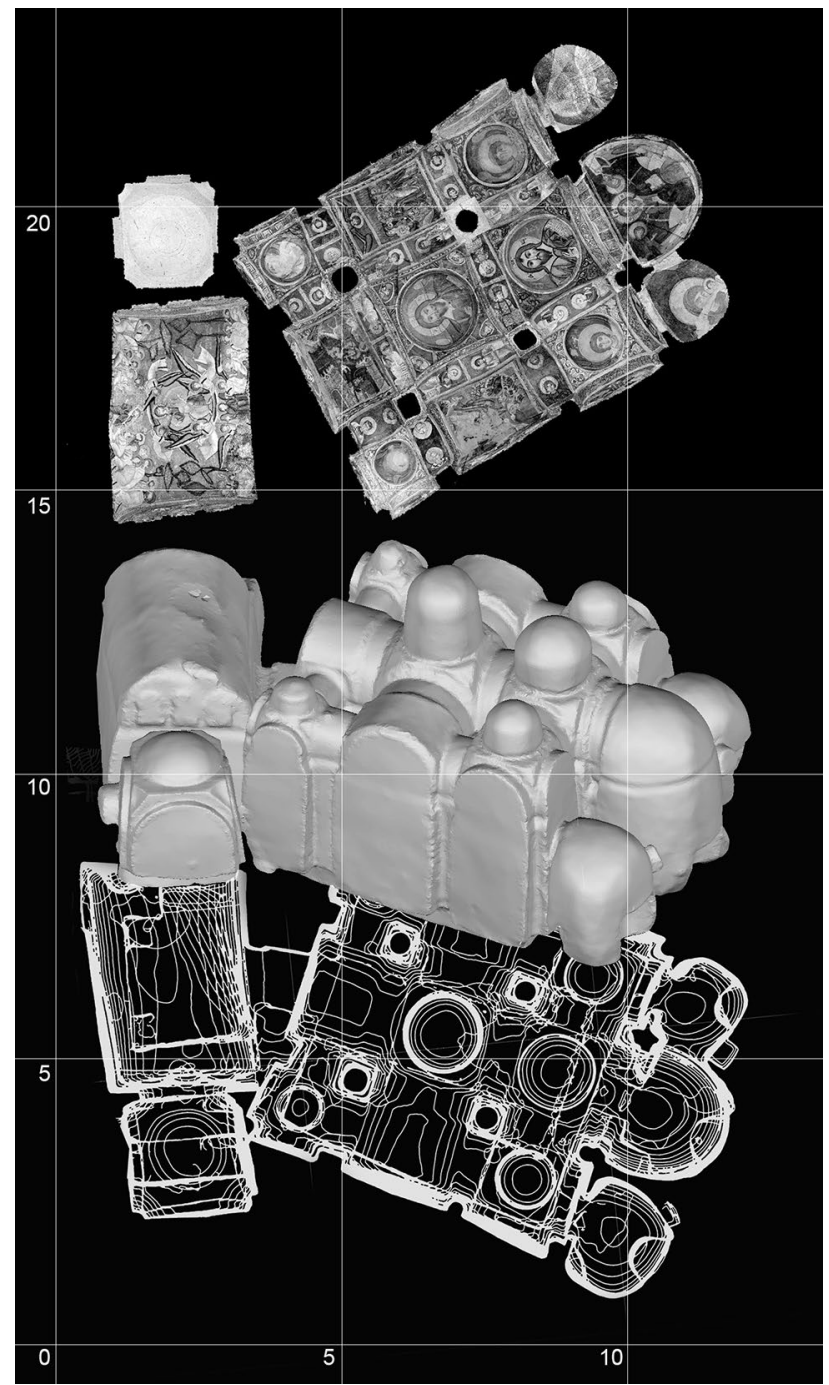

Fig. 2 Karanlık Kilise in Goreme, Turkey as a typical Byzanthine-style quincunx church. Mapped, rectified plan of vaults, contour-lines plan and three-dimensional view of interior space from mathematical model after digital topographic survey (model by M. Carpiceci; view by F. Colonnese)

to Renaissance forms is played by Renaissance architects such as Antonio Averlino, known as Filarete, Francesco di Giorgio Martini and Leonardo da Vinci. Filarete, who uses diagrams and the ad quadratum method to develop his projects, proposes a quincunx-shape church for the Ospedale Maggiore in Milan through a grid that allows him to size both the internal spaces and the thickness of walls (Niebaum 2009). Many of Leonardo's design schemes are based on the tetrastylon quincunx (Fig. 4), which is used as an elementary scheme able to express the idea of centrality and to be hybridized with octagonal and radial 


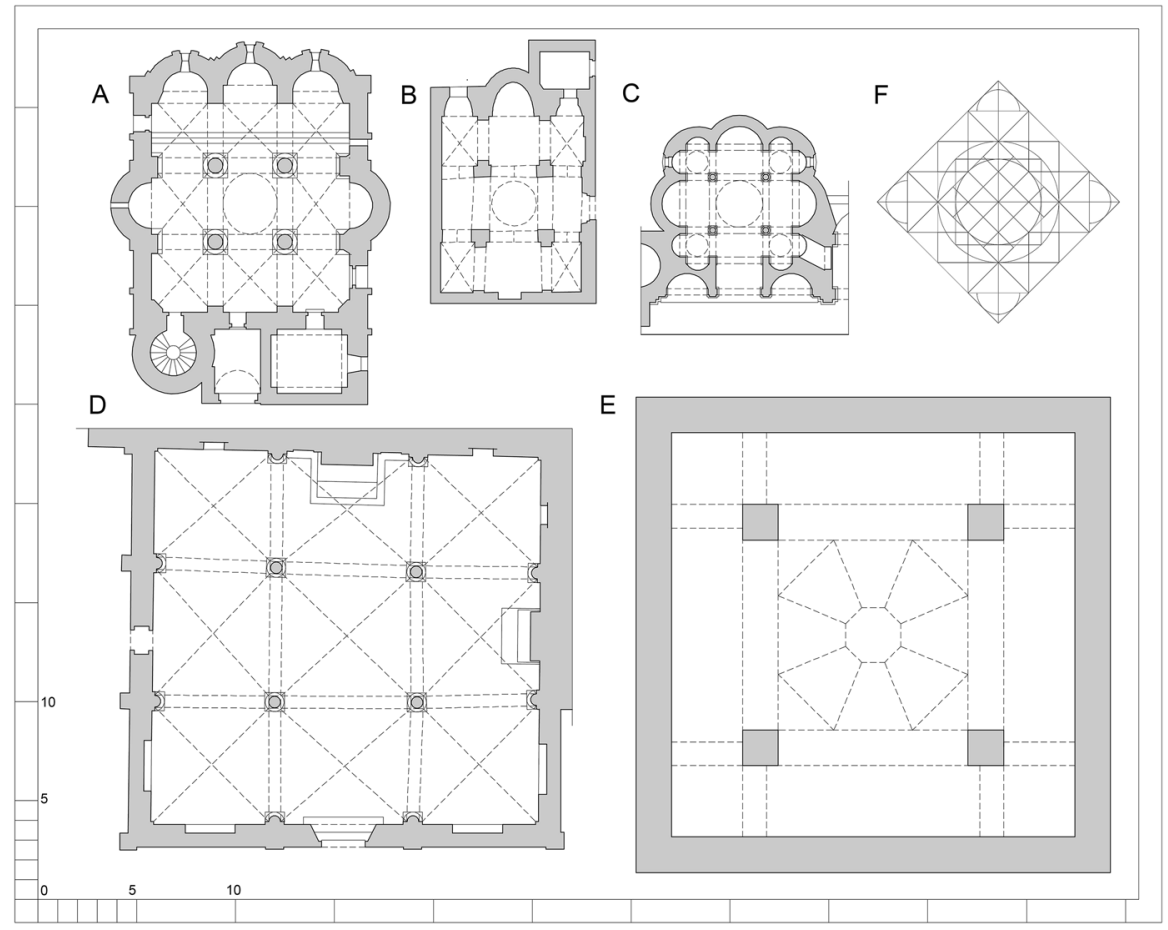

Fig. 3 Examples of quincunx plans in Italy: a S. Vittore alle Chiuse, Genga; b S. Michele Arcangelo, Amalfi; c Alessio Tramello, Chapel of S. Sisto, Piacenza, 1513; d S. Maria del Portico in Fontegiusta, Siena, 1482; e Filarete, Church design for Ospedale Maggiore (Reconstruction); f Francesco di Giorgio, Church designing diagram after Codex Magliabecchianus II.I.141, fol. 42

schemes (Carpiceci and Colonnese 2019). Leonardo was surely engaged in experimenting with quincunx schemes with different ratios between the parts as the four squares at the corners may have the same size or be smaller than the central one. The rectangles that form the arms of the cross have the longer side that corresponds to the side of the larger square and the smaller side that corresponds to the side of the smaller square. Eventually, they represent a figure mediating between the two squares, and the inclination of the diagonal embodies this relationship. As the height of vaults was generally proportional to the side, the architect could size the main elements of the building simply by defining the triangle whose sides are the two squares' sides, in a sort of fascinating geometric control tool (Fig. 5).

The geometrical explorations of the quincunx grounded the Renaissance studies on the centric, Greek-cross churches (Fig. 6) up to Michelangelo's proposals for S. Giovanni dei Fiorentini in 1559 but they definitely climaxed in Bramante's plan for S. Pietro (Bruschi 1985) as well as related developments. On fol. 1954Av at the Uffizi, for example, the plan of the church of Sts. Celso and Giuliano is surrounded by a network of walls that seem to reveal the underlying mathematical grid (Ray 


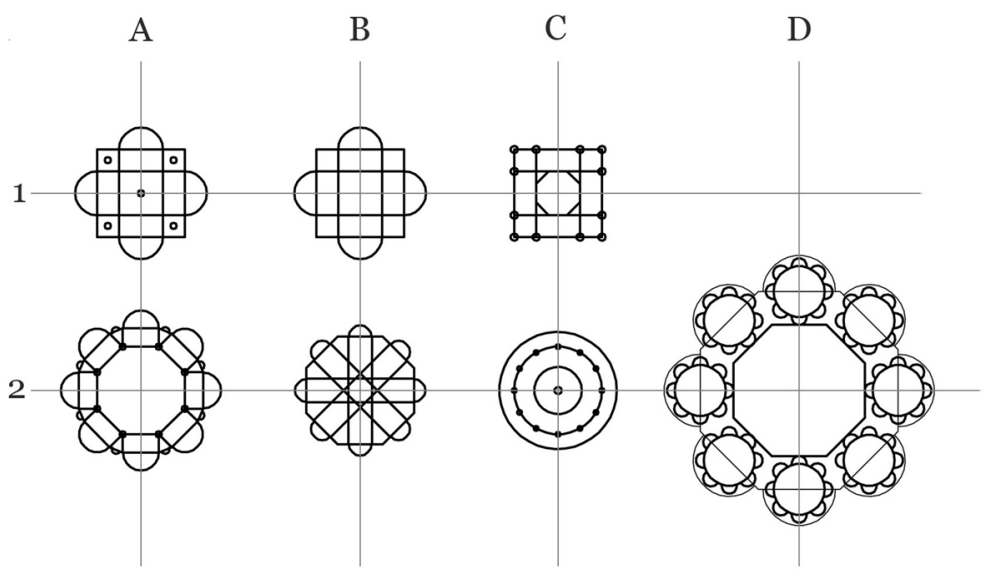

L At $104 \mathrm{r} \perp$

At 1010 r

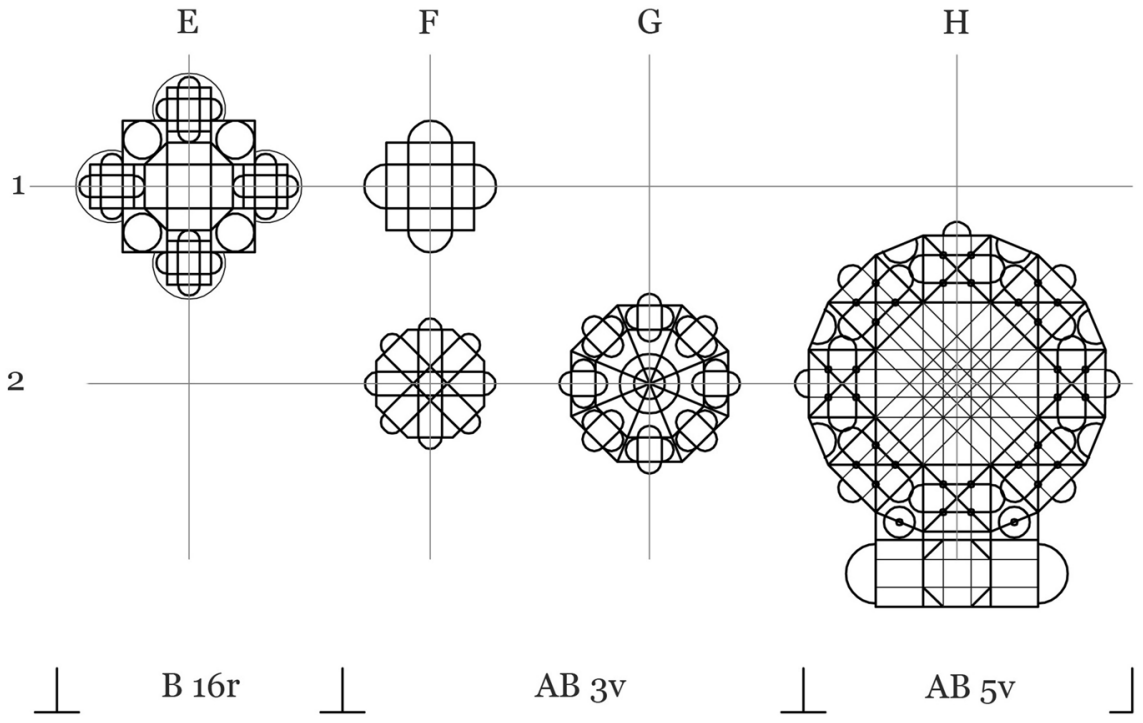

Fig. 4 A selection of diagrammatic plans after Leonardo da Vinci's design sheets from Codex Atlanticus (At), Codex B (B) and Codex Ashburnham 2037 (AB) (drawing by M. Carpiceci)

1984: 65). On the one hand, Bramante drafted a grid in his famous Parchment Plan for St. Peter's to compute the size of elements (Hubert 2014) and to help the observer measure the design space (Pérez-Gómez 2016: 255), but the effects of the "mathematization" on the architectural orders can be seen in the convent of S. Maria della Pace, too (Bruschi 1985: 119-120). On the other, he adopted the quincunx as 
a pattern for the floor of the Tempietto (Freiberg 2014), in a project preserved in the Ambrosiana Library (Adorni 1998) and in the plan of St Peter's church as well. A few years later, his follower Cesare Cesariano adopted the same pattern to illustrate the ancient temples and discuss their elements and typologies on fol. 52 of his commented version of Vitruvius's De Architectura libri decem (Jobst and KleefischJobst 1994: 439), electing the quincunx as the "templum antiquum" par excellence.

The enigmatic project by Jacopo Tatti, known as Sansovino, which won the competition for S. Giovanni dei Fiorentini in 1519, was also based on quincunx, and according to Hubertus Günther (1995), its plan can be seen in a perspective drawing presented by Sebastiano Serlio in his Third Book. Here, following the tradition of perspective inlays, Serlio adopts a monumental architecture to show the visual effects of perspective, eventually demonstrating the strict relationship between square grid and perspective visualization, whose procedures and figurative consequences would deserve a specific study.

When looking at the plan for S. Giovanni and trying to reconstruct it (Fig. 7), irregularities and adjustments emerge. They can be attributed to Serlio's need to rework Sansovino's original plan on a square, regular $18 \times 18$ grid, both to simplify the overall design and to insert it clearly in the perspective grid (actually, the fundamental module of the project is generated by the subdivision of the central octagon side, from which the size of the architectural order derives).

In the same decades, commissioners and architects promoted a process of sacralization of the residential architecture. This process involved not only semantic elements such as the dome or the pediment supported on columns, but also quincunxbased plans. While in the case of isolated palaces, the central bay turns into an arcaded courtyard, as prescribed by Leon Battista Alberti, the villas show different solutions. Among the residential diagrams transcribed by Francesco di Giorgio Martini on his treatise, which reached Leonardo, Giuliano da Sangallo, Baldassare Peruzzi and Serlio, several applications of both quincunx scheme and $3 \times 3$ grid can be found. By 1487, Giuliano da Maiano adopted the quincunx for the villa in Poggio Reale, Naples, which was soon abandoned and handed down to posterity by means of an incongruous, controversial drawing by Serlio. The mathematical location of pillars and walls in Serlio's plan, derived from Peruzzi's and Donati's ideal studies at the Uffizi (fols. 15Abis and 1996A), reveals the underlying grid while the ideal character of the drawing emerges both from the incongruences of windows between the plan and the elevation, and from the absence of a true staircase, replaced by four Lilliputian round staircases carved in the corners of the courtyard. In contrast, in the villa plan in the Sallustian Codex in Turin, Martini preserves the purity of the scheme and the courtyard in the central module by placing the staircase in an outer cylinder embraced by a curved loggia, which gives the entire plan an evocative church shape. The fol. 11r of the Barberini Codex, Latin 4424 in the Vatican Library, shows Giuliano da Sangallo's plan of a residential complex composed of two blocks, one of which is designed on a $3 \times 3$ grid (Frommel 2002): around a central octagonal hall, perhaps intended for a private chapel, there are four apartments in the corner bays and four different courtyards in the arms of the cross, almost demonstrating the several combinations offered by the plan. Leonardo also proposes the quincunx as a residential scheme both in projects for octagonal-shaped houses, in which a 


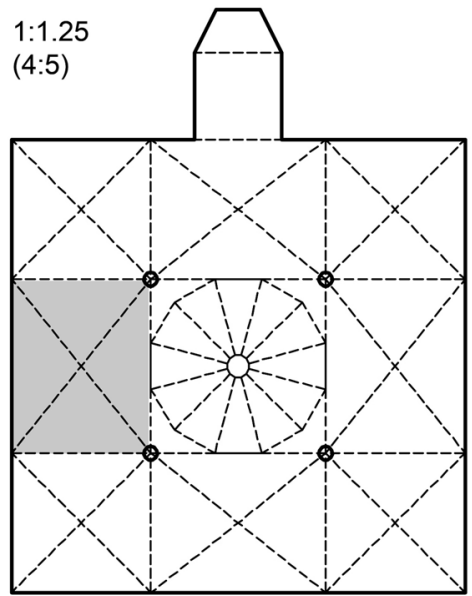

BRAMANTE

Prevedari Perspective Temple

$1: 2$

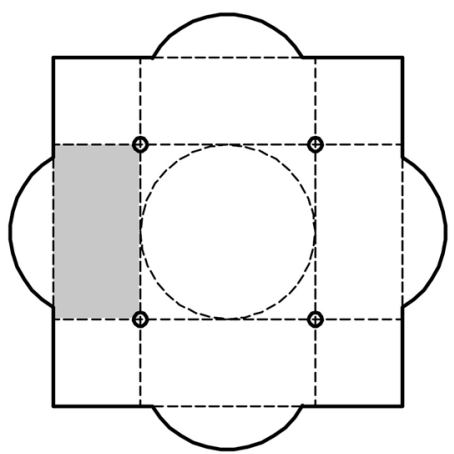

BRAMANTE (?)

Cat.1025, Coll. 251 inf., n.84 Ambrosiana Library

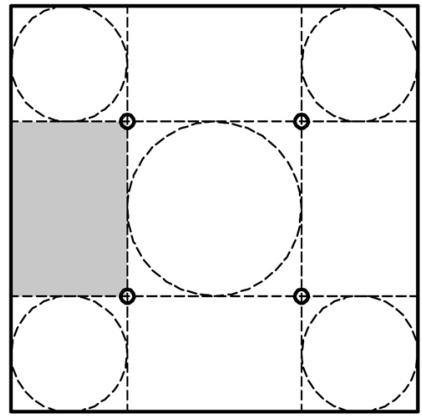

\section{FILARETE}

Ospedale Maggiore

$1: 3$

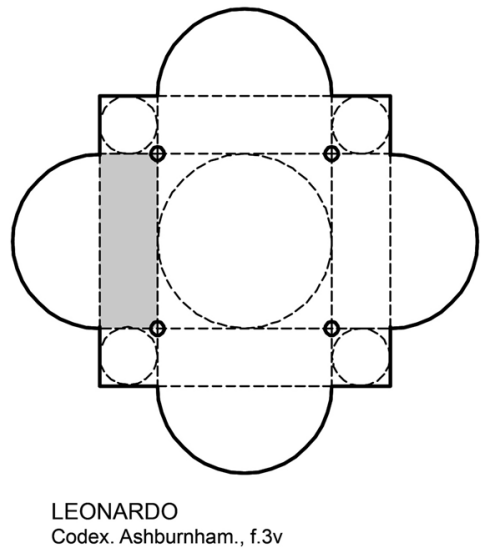

Fig. 5 A proportional comparison between quincunx church diagrams with different ratios between the sides of the rectangular bay

cross-shape staircase occupies the central bay (Codex Atlanticus, fol. 317r/114v-a), and as a princely residence. While the fols. $271 \mathrm{va}(732 \mathrm{bv})$ and $231 \mathrm{rb}(629 \mathrm{~b})$ in the Atlanticus show small plans inspired precisely by Poggio Reale and attributed to a villa for Charles d'Amboise (Frommel 2012), the fol. 18v in Manuscript I/2180 in Paris shows a detailed plan study for a quincunx-shaped villa which, according to Frommel (2006), contains elements for alternative solutions, in particular for the position of the staircase (Fig. 8). 

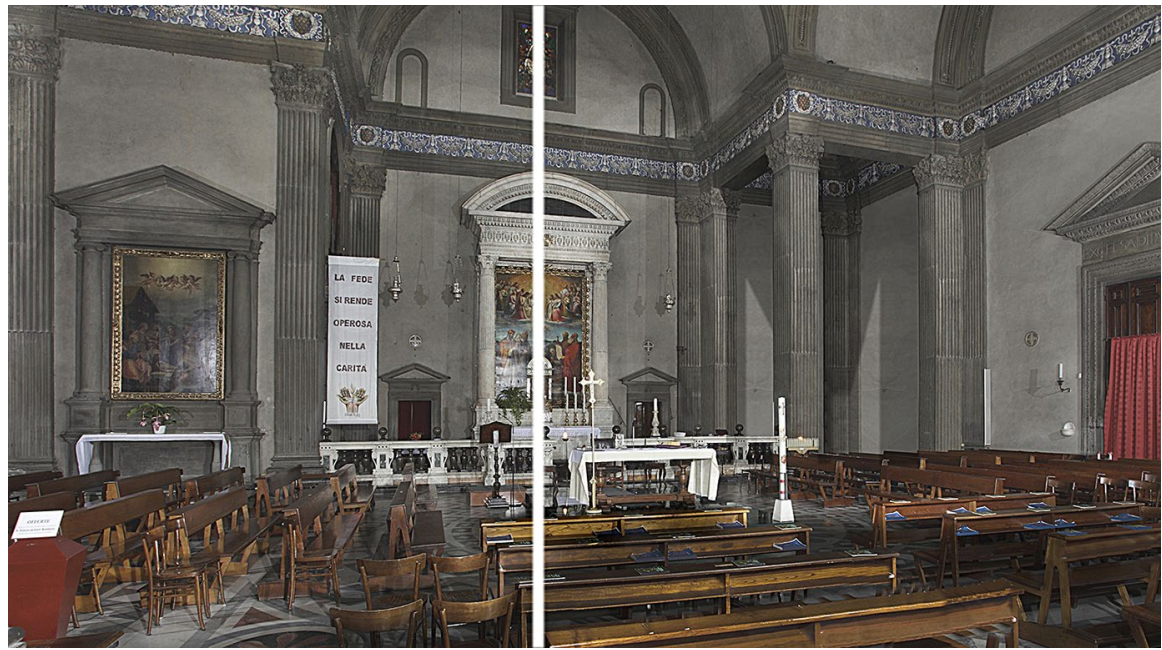

Fig. 6 Giuliano da Sangallo, S. Maria delle Carceri, Prato, 1486-95. The right half of the interior photomontage, with a corner cell "carved" behind the architectural orders, reveals the implicit quincunx hidden in the Greek-cross scheme

\section{Das Italienische Lusthaus}

At the end of the sixteenth century, the process of mathematizing the architectural composition as well as the diffusion of grid-based perspective procedures can be observed in the early use of the grid in designing parterres and gardens, in the work of both Dutch architect Hans Vredeman de Vries and his many followers, such as Johann Peschel and Daniel Loris (Colonnese 2018; Fitzner 2015: 164-169). Between 1630 and 1680, German and Dutch architects such as Adriaan Dortsman in the Finspång Castle or Nicolaus Goldmann, a teacher of architecture in Leiden, "used arithmetical grid systems as well as geometrical constructions to achieve unity and coherence within their designs" (Ottenheym 2014: 1). In this field, Goldmann constitutes a fundamental bridge between Renaissance and Neoclassicism, and even beyond. Inspired by the description of the Temple of Solomon, which he reconstructed in form of a huge square $3 \times 3$ grid, he produced hundreds of designs as a teaching tool to explain his principles based on whole numbers and basic ratios such as 1:2, 2:3 and 3:4 (Goudeau 2005: 327-342). Most of them were illustrated and published after his death in the successful book Vollständige Anweisung zu der civil Bau-Kunst by Leonhard Christoph Sturm (1696). Goldmann states the most economical way of designing an ordinary house is to make each room the same size and defines this type as the Italienische Lusthaus, the Italian pleasure house (Sturm 1696: 149). In particular, Das freystehende Haus (Sturm 1696: pl. 70 , referred to Book 4, chap. 21, p. 148), a cubic villa on a square ground plan of $30 \times 30$ modules (Fig. 9), shows a circular staircase, which he defines as a Schacht, in the middle and is divided "into nine squares of $10 \times 10$ modules, with outer walls 2 modules and inner walls 1 module wide, thus creating nine inner spaces of $8 \times 8$ 

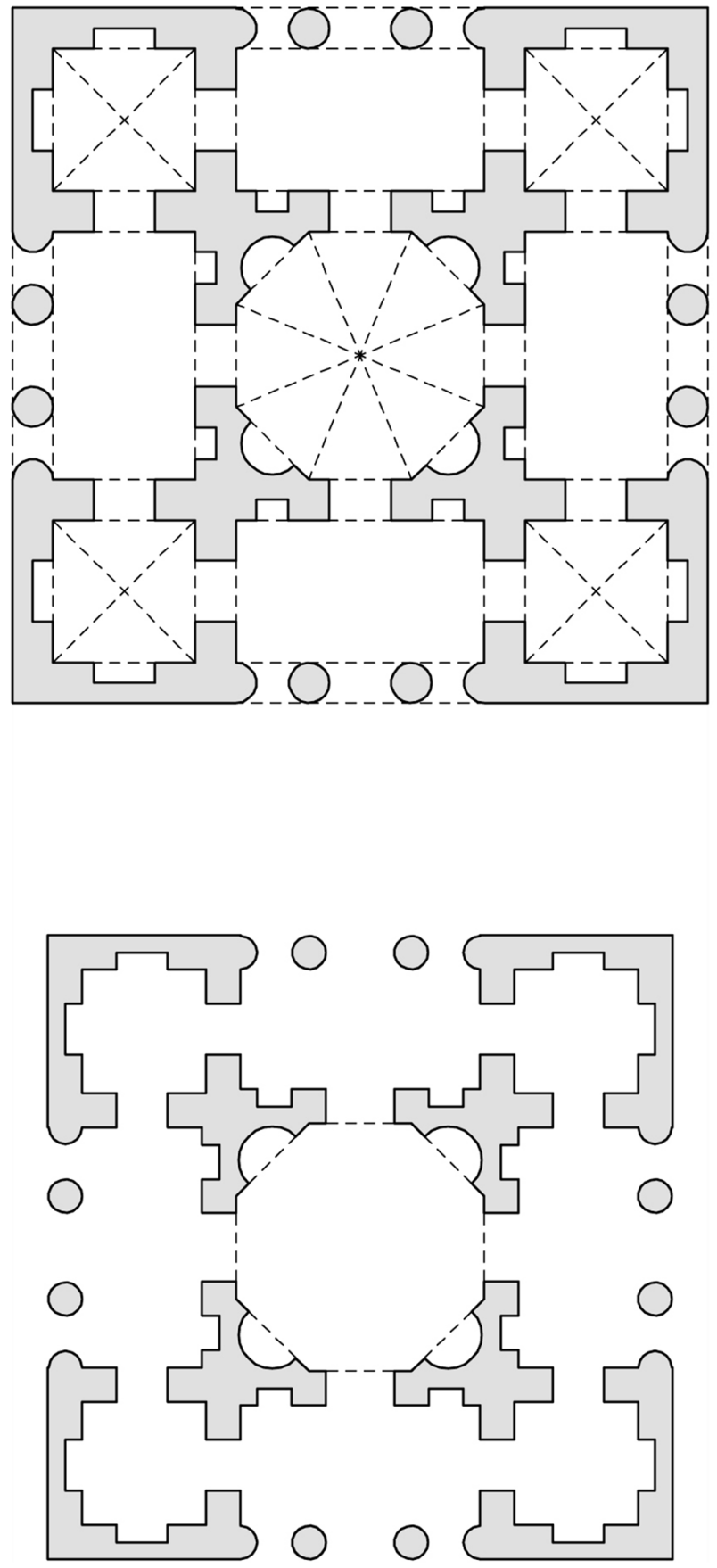

Fig. 7 Jacopo Sansovino (attributed to), Plan of S. Giovanni dei Fiorentini according to Sebastiano Serlio, 1519. The upper reconstruction follows Serlio's $18 \times 18$ grid while the lower one results from the division of the octagon side in six parts 
modules" (Ottenheym 2014: 3) as a sort of rational quincunx whose programmatic indeterminacy can perhaps be associated to Robin Evans's considerations on the Italian Renaissance house as "a matrix of discrete but thoroughly interconnected chambers" (Evans 1997: 64).

In 1755, William Chambers, who had just got back from his five-year Italian sojourn, designed the Casino Marino in Dublin for Lord Charlemont derived from Goldmann's model, just adding free columns outside and varying the layout of stairs and kitchen in order to obtain a rectangular hall. Parallel to this, applications of quincunx can be appreciated both in Lord Burlington's Chiswick House at London in 1729 and, 50 years later, in Thomas Jefferson's garden pavilion for Monticello, translated from Sansovino's plan on Serlio's book (1779-1781, Coolidge Collection of Thomas Jefferson Manuscripts, Massachusetts Historical Society, N62, K35).

Besides the use of the grid as an extensive, abstract system of design proposed by the Turin-based architect Bernardo Vittone in both his treatises, Istruzioni Elementari (1760) and Istruzioni Diverse (1766) (Pérez-Gómez 1983: 109), the influence of Goldmann and his Italienische Lusthauss can be found up to Karl Friedrich Schinkel, in particular in the pavilion built in the park of the Palace of Charlottenburg at Berlin in 1825: designed to evoke the Prince's stay in Naples, this Italian-style building shows a regular plan based on a $3 \times 3$ grid of rooms with a staircase in the center, which eventually causes the shifting of one of the internal walls.

In almost the same years, Jean-Nicolas-Louis Durand's Précis of the Lectures on Architecture presented the plan composition as a sort of architectural algebra, combining ideas from both Vittone (Picon 2000: 41) and Goldmann (Goudeau 2015). The students were called to work on gridded paper and to think of design as a mathematical problem to solve (Picon 2000: 41), picking-up pieces from the matrix of his Ensembles d'Edifices, in which he dedicates one column to elements based on a $3 \times 3$ grid and two columns to elements based on a $4 \times 4$ grid (with only one on a $5 \times 5$ grid) and applies the quincunx pattern to designs for museums and other emerging typologies (Fig. 10).

\section{The Nine-Square Grid Problem}

The twentieth century opens with Frank Lloyd Wright's Unity Temple, built in 1908 in Oak Park, Illinois, where the ancient quincunx plan is somehow used to celebrate the innovative potential of a modern architecture conceived as an orchestrated assemblage of lines, planes and volumes, at nearly the same time that Le Corbusier was sketching quincunx churches during his Voyage d'Orient.

In the 1950s, a group of architects and professors of the School of Architecture at the University of Texas promoted a new pedagogic approach to architectural design largely based on drawing. The group, comprised of the historian Colin Rowe, the painter Robert Slutzky, Bernhard Hoesli (a former assistant of Le Corbusier), and the architects Werner Seligmann, Lee Hirsche and John Hejduk (Caragonne 1995), began to ask their students to conjecture designs on a pre-existing structural grid of pillars and beams that defined nine square bays. The so-called "nine-square 
A
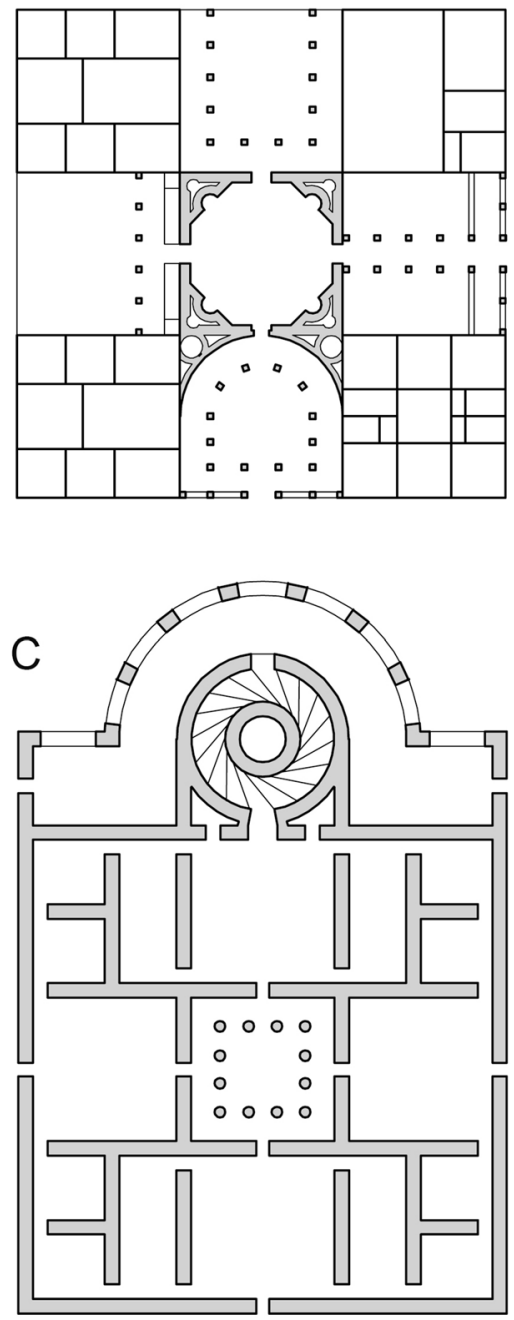

B

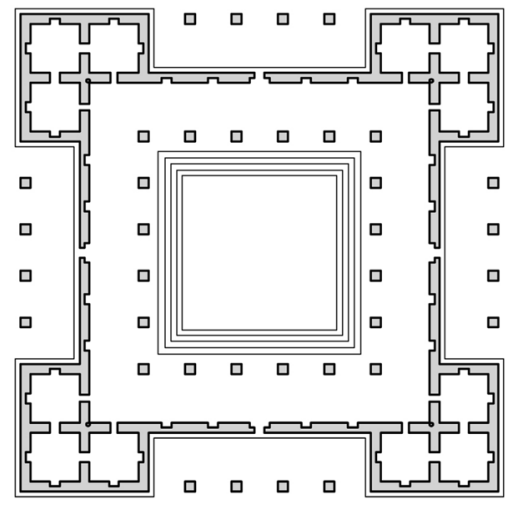

D

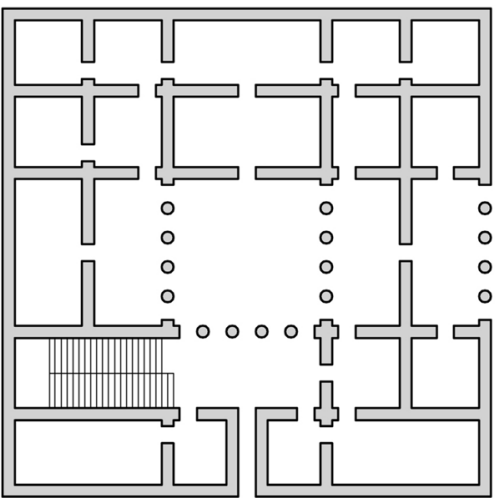

Fig. 8 Reconstructions of Renaissance quincunx-shaped villas: a Giuliano da Sangallo, fol. 11r, Codex Barberini, Latin 4424, Vatican Library, Rome (upper half); b Giuliano da Maiano, Villa at Poggio Reale according to Serlio; c Francesco di Giorgio Martini, fol.19v, Codex Salluziano 148, Royal Library, Turin; d Leonardo da Vinci, fol. 18v, Ms. I/2180, Institut de France, Paris

grid problem" was quickly adopted in other architecture schools in the USA as a fundamental exercise in architectural design to face Le Corbusier's paradigm of plan libre. It provided many post-war architects with a flexible lay-out that could be used to design a number of typologies, from private houses to small public buildings. Some of the Texas Houses designed by Hejduk himself between 1954 and 1963 reveal the potentials of a quincunx-shaped iron pillars-and-beams structure. 
In particular, while the House 4 still shows walls aligned with the thin pillars, the House 5 presents a free disposition of furniture pieces that eventually contests the pattern and, almost colonizing a preexisting structure, organize it as a flowing, open space (Fig. 11).

The didactic and professional success of this exercise can be attributed to the scheme providing a balanced mix of centricity and seriality but also to parallel researches in history and biology, which changed the way of looking at the precedents. In the 1940s, the historical studies by Wittkower (1944) and Rowe (1947), later one of the "Texan Rangers", had introduced formalistic analysis of Palladio's villas with diagrams illustrating patterns and proportional relationships. Abruptly, these analyses promoted a direct comparison between buildings of different ages, such as Rowe's comparison between Palladio's Villa Malcontenta with Le Corbusier's Villa Stein-De Monzie, openly addressing the mathematical aspects of the ideal villa. Indirectly, these studies contributed to enhance the status of the "nine-square grid problem": already a design lay-out for contemporary buildings, it was assumed as an a priori scheme that could be used to analyze Greek, Roman or medieval buildings. Both senses are present in the work of Oswald Mathias Ungers. Since the 1975, the German architect has been designing buildings based on a square matrix constantly dealing with historical models and exploring multiple subdivisions of the quincunx. The first significant project concerns an irregular area in Marburg he organized according to a $3 \times 3$ grid in which the individual square lots are separated by a distance equal to $1 / 6$ their side. He elaborates alternatives of each of the square houses according to an internal $3 \times 3$ grid while the arrangement of the windows suggests an external division into 7 parts. Over the ensuing twenty years, Ungers declined the quincunx on a square grid in many ways, often exhibiting it in the elevation design as well. In particular, he developed a $5 \times 5$ grid in the exhibition structures for the Sieben Variationen des Raumem and Kubus, from 1985 to 1990 ; a $7 \times 7$ grid for a tower at Berlin Kulturforum, in 1983; a $9 \times 9$ grid for the Museuminsel at Hamburg in 1986; a $11 \times 11$ grid for his cubic house at Utscheid in 1986; and a $13 \times 13$ grid for the housing block in Bernburgerstrasse at Berlin, in 1986 (Fig. 12).

However, Ungers designed all of these grids to adapt the original quincunx organization in nine cells visible and efficient for buildings of different typology and size. Inspired by Louis Kahn's organization of space in serving and served spaces and his development of hollow walls and pillars (Cacciatore 2016), he gives the center either a service function, by inserting a staircase like Goldmann or Schinkel, or a served one, by accumulating services and stairways in other symmetrical bays.

Besides the number of contemporary architects still adopting the quincunx as a scheme for residential buildings - see the recent houses by either Alberto Campo Baeza or Emilio Tuñon-a further step is provided by the opportunity of distorting the grid. This has been recently enhanced by digital tools but can be dated back to the inspiring diagrams illustrating the growth and development of organisms presented by D'Arcy Thompson's On Growth and Form (1917), which provided architects like Frank Lloyd Wright with an organic, science-based metaphor for art and architecture (Laseau and Tice 1992) and the opportunity to consider the 
Fig. 9 Plan comparison between Nicolaus Goldmann's seventeenth-century cubic house and Karl Friedrich Schinkel's pavilion by the Palace of Charlottenburg at Berlin, 1825
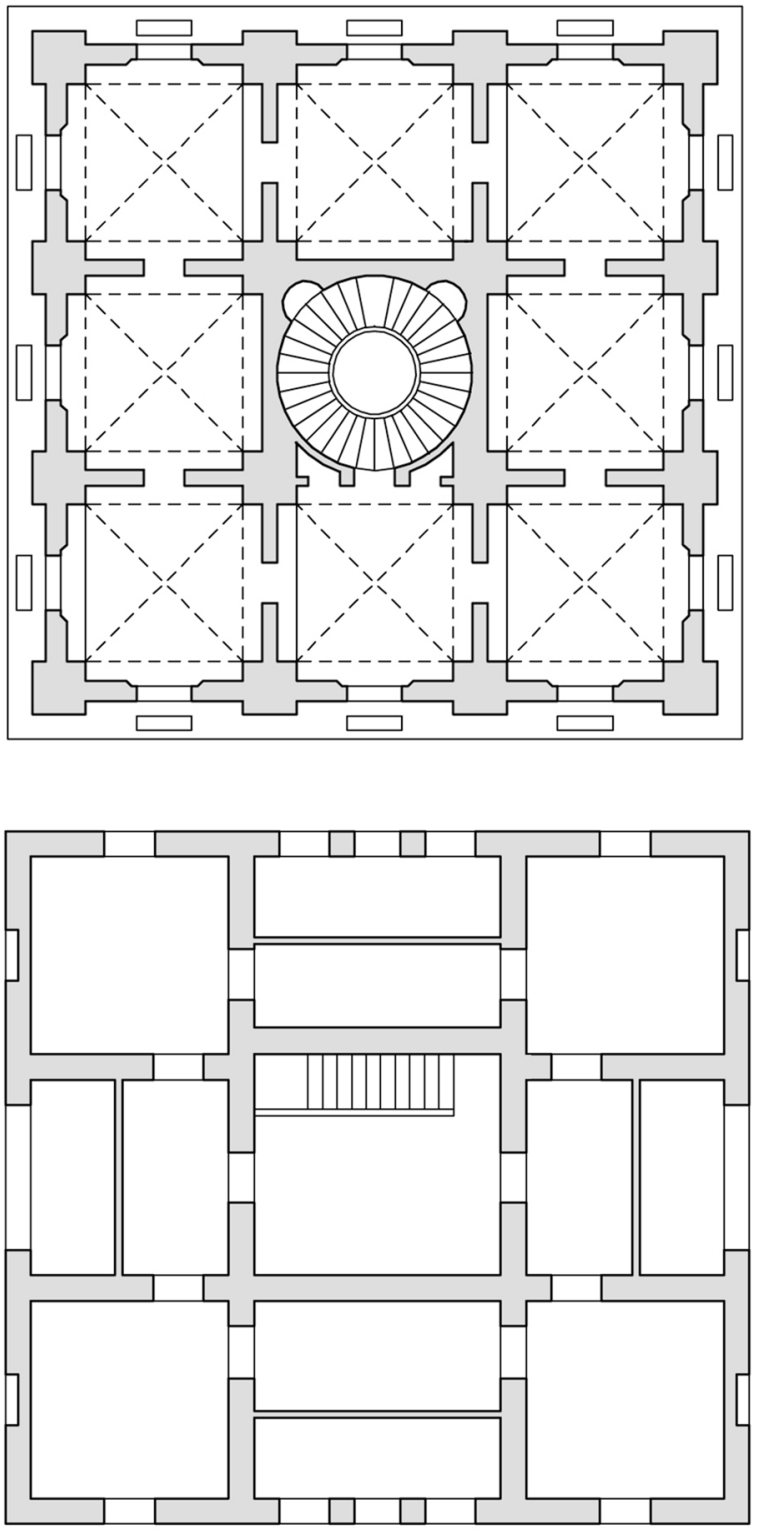

deformation as an expressive, contextualizing agency. An example of this approach can be seen in Herzog and DeMeroun's Köchlin Haus in Basel-Riehen, a steel-andglass three-storey house built in 1995 around a central patio (Fig. 13). First, the two upper U-shaped levels are mutually rotated to address the patio from different directions and then the $3 \times 3$ grid the house is based on is deformed to adapt the plan to the irregular shape of the site. The final plan on the one hand provides the core with light, air and views on the surroundings, especially by opening the wings 

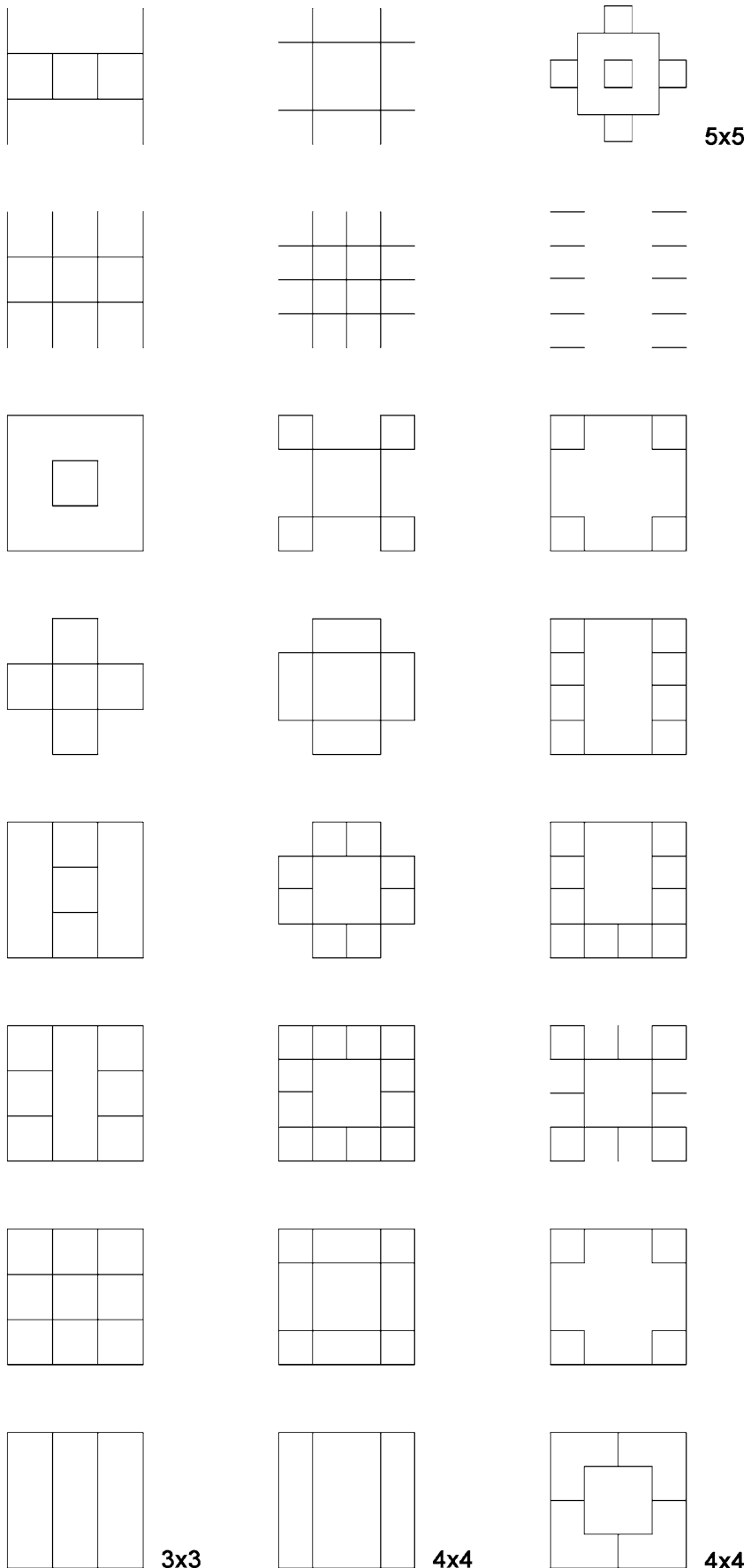

$3 \times 3$
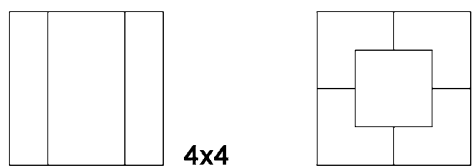

Fig. 10 Jean-Nicolas-Louis Durand's square patterns from Précis of the Lectures on Architecture, 180205 

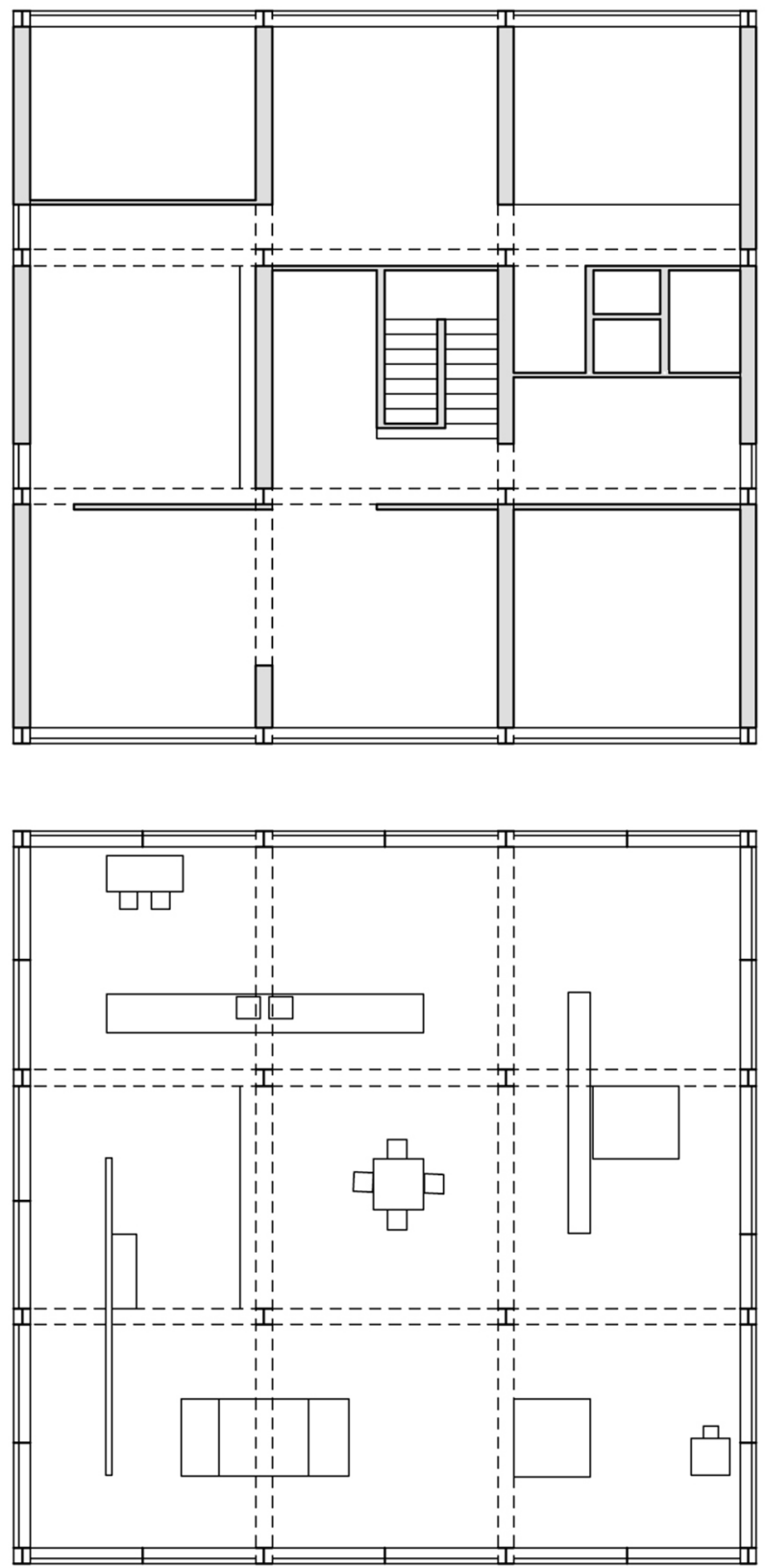

Fig. 11 Comparison between ground floor plans reconstructed from John Hejduk's Texan House 4, with internal walls emphasizing the structure, and Texan House 5, with the application of Le Corbusier's plan libre 
A
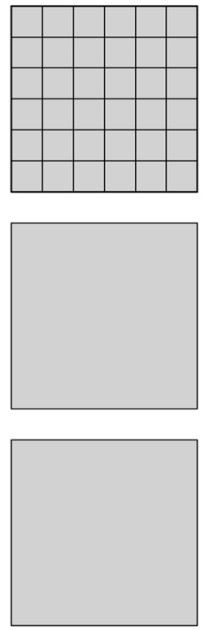

C
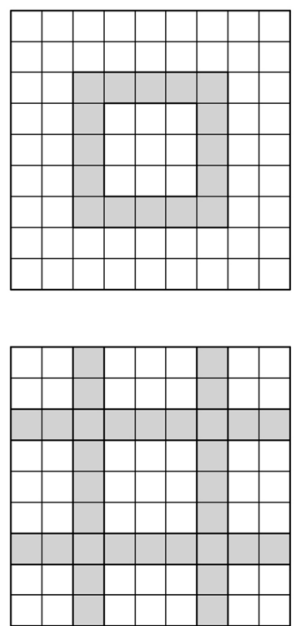

B
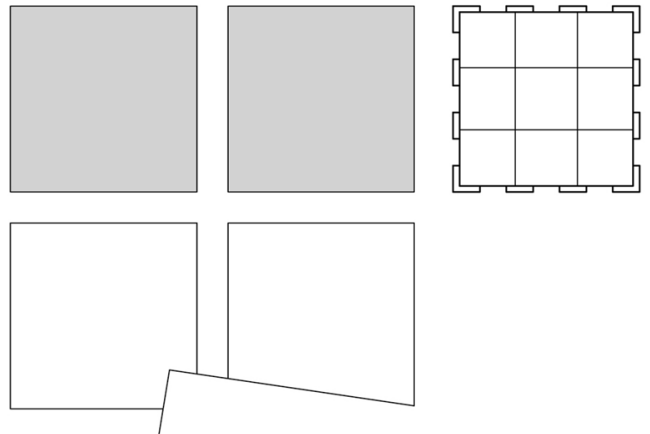

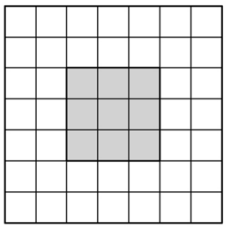

E
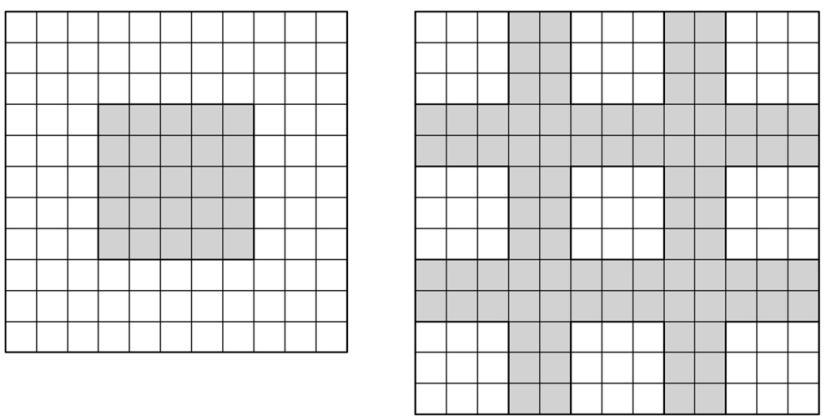

Fig. 12 A selection of Oswald Mathias Ungers' quincunx based plans (serving areas in grey): a Housing in Marburg and typic floor of one of the houses, 1975; b Tower at Berlin Kulturforum, 1983; c Museuminsel at Hamburg, 1986; d Private house at Utscheid, 1986; E) Housing block in Bernburgerstrasse, Berlin, 1986 (color figure online) 


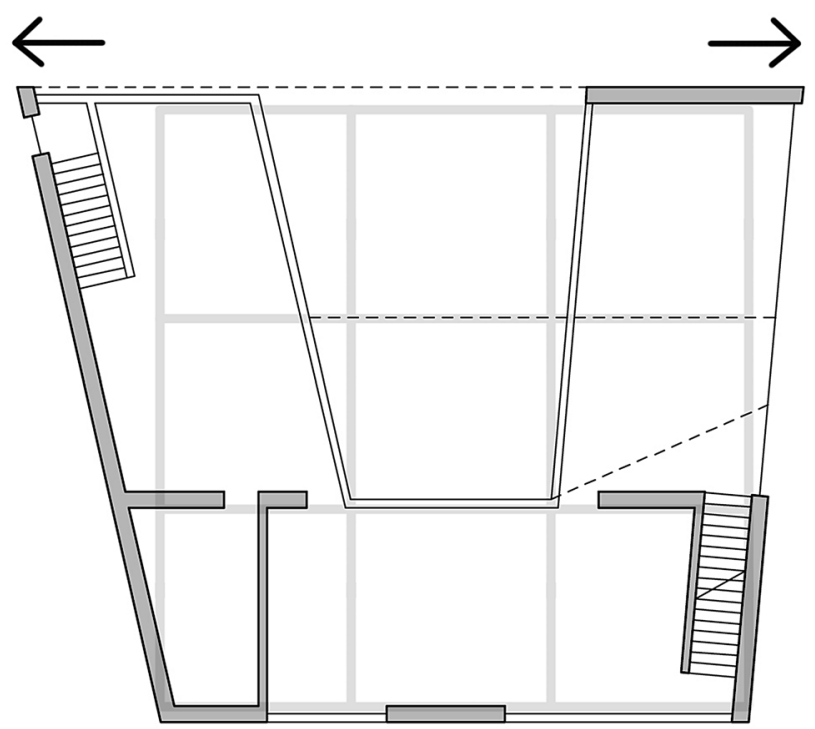

Fig. 13 Herzog and De Meuron's Köchlin Haus in Basel-Riehen, 1995. Reconstructed plan of the first floor with the ideal primitive $3 \times 3$ grid in grey (color figure online)

at the first floor and, on the other, keeps all of the indoor spaces introverted and interconnected through the huge glass walls onto the patio.

\section{Conclusions}

Alexander Purves states that, "The origin of a particular form is beyond our understanding. We can, however, observe the persistence of forms. Those that persist do so because they resonate so strongly in the experience of human beings that they are chosen again and again" (1982: 132). Many architects through time elected the quincunx (and the $3 \times 3$ grid) as a design layout for both its semantic and geometric features. In the late Middle Ages and early Renaissance, the fortune of the quincunx plan was its implicit reference to antiquity, to be related to actual buildings, such as S. Lorenzo in Milan and S. Sofia in Constantinople, their sites, and their oriental origins. Later, the quincunx persistence is due to its capability to express symbolic hierarchies through the articulation of volume and plan; to be transformed in geometry, proportions and elements; to offer a criterion for placing and sizing architectural elements and to easily pass from two-dimensional to three-dimensional structures; to embody different themes and functions; and possibly to work as a mediator between the proportional idea derived from Vitruvius' pages, the medieval ad quadratum practice and the almost metaphysical grid drawn under plans and perspectives. Being crossfertilised with formal and typological suggestions from different sources, the quincunx passed from religious to civil buildings. While in the early sixteenth 
century it exemplifies the very idea of antique temple, certified by Cesariano's Vitruvius, after the success of the Villa at Poggio Reale, it came to embody the peculiar idea of the Italian pleasure house. This is testified by the designs of Goldmann, Burlington, Chambers and Schinkel, which identify the stairway as the main design question to be solved in relationship with the central cell and its symbolic and spatial importance.

As a fundamental pattern of Durand's "construction kit", the quincunx is applied as an attribute of symmetry, centricity and monumentality to a number of cases and typologies but the development of reinforced concrete opens it to new opportunities. While in its applications in residential architecture the quincunx had turned into a structure of closure and separation, with walls bordering the nine cells, Hejduk's designs based on the "nine-square grid problem" gave it back a sense of openness and visibility. Texas Rangers' applications turned the quincunx into an a-temporal design tool which provided also new interpretations of the historical buildings, indirectly feeding the advent of Postmodern. This is exemplified by the work of Ungers, who used the grid as a quincunx functional extension which is able to deal with the problems connected to different sites and sizes, to accord to the standards of building industry complements, and to give his designs a persisting sense of classic, "atemporal" harmony. Conversely, the "deformed" quincunx, here described through Herzog and de Meuron's Köchlin Haus, overcomes both the stratified memory of the ancient model and the "ninesquare grid problem": it rather represents the instable, pragmatic and dynamic human perception winning over the world of geometry and ideas, as a grid roughly sketched on a sheet, waiting for a game of tic-tac-toe or a new design to come.

Acknowledgements This article constitutes a personal development from a previous article focusing on Leonardo da Vinci's designs (Carpiceci and Colonnese 2019). I wish to thank Marco Carpiceci for his help and agreement to use his drawings. All figures are by the author unless otherwise noted.

Funding Open access funding provided by Università degli Studi di Roma La Sapienza within the CRUICARE Agreement.

Open Access This article is licensed under a Creative Commons Attribution 4.0 International License, which permits use, sharing, adaptation, distribution and reproduction in any medium or format, as long as you give appropriate credit to the original author(s) and the source, provide a link to the Creative Commons licence, and indicate if changes were made. The images or other third party material in this article are included in the article's Creative Commons licence, unless indicated otherwise in a credit line to the material. If material is not included in the article's Creative Commons licence and your intended use is not permitted by statutory regulation or exceeds the permitted use, you will need to obtain permission directly from the copyright holder. To view a copy of this licence, visit http://creativeco mmons.org/licenses/by/4.0/.

\section{References}

Adorni, Bruno. 1998. Alessio Tramello. Milano: Electa. Bruschi, Arnaldo. 1985. Bramante. Roma-Bari: Laterza. 
Cacciatore, Francesco. 2016. Wall as Living Place: Hollow Structural Forms in Louis Kahn's Work. Siracusa: Lettera Ventidue.

Caragonne, Alexander. 1995. The Texas Rangers: Notes from the Architectural Underground. Cambridge, MA and London: MIT Press.

Cardamone, Caterina. 2000. Origine e modelli delle chiese quattrocentesche a quincunx. Quaderni di palazzo Te 7: 12-37

Carpiceci Marco, Colonnese Fabio. 2019. The Quincunx as Architectural Structure. Geometry and Digital Reconstructions after Leonardo Da Vinci's Centralized Plan Temples. In Proceedings of the 18th International Conference on Geometry and Graphics. ICGG 2018. Advances in Intelligent Systems and Computing, ed. Luigi Cocchiarella, 1907-1918. Cham: Springer.

Colonnese, Fabio. 2015. The Tomb of Porsenna. Textual and graphical translations of Pliny's Labyrinthus Italicus. In Traduire l'architecture: Texte et image, un passage vers la création, eds. Robert Carvais et. al., 161-172. Paris: Picard.

Colonnese, Fabio. 2018. The Labyrinth as an Architectural Mediator: Vredeman De Vries and the Geometric Garden in The Netherland. In Enchanted, Stereotyped, Civilized: Garden Narratives in Literature, Art and Film, eds. Sabine Planka and Ferya Cubukcu, 435-454. Würzburg: Königshausen \& Neumann

Evans, Robin. 1997. Figures, Doors and Passages. In Translations from Drawing to Building. Cambridge, MI: The Mit Press.

Fitzner, Sebastian. 2015. Architekturzeichnungen der deutschen Renaissance. Funktion und Bildlichkeit zeichnerischer Produktion 1500-1650. Cologne: Modern Academic Publishing.

Freiberg, Jack. 2014. Bramante's Tempietto, the Roman Renaissance, and the Spanish Crown. Cambridge, MA: Cambridge University Press.

Frommel, Sabine. 2002. Lorenzo il Magnifico, Giuliano da Sangallo e due progetti per ville del Codice Barberiniano. In Il Principe architetto,ed A. Calzona et al., 413-454. Firenze: Olschki.

Frommel, Sabine. 2006. Leonardo da Vinci und die Typologie des zentralisierten Wohnbaus. Mitteilungen des Kunsthistorischen Institutes in Florenz 50 (3): 257-300.

Frommel,Sabine. 2012. Leonardo and the Villa of Charles d'Amboise. In Leonardo da Vinci \& France, ed. Carlo Pedretti, 117-125. Poggio a Caiano: CB Publishers.

Goudeau, Jeroen. 2005. Nicolaus Goldmann (1611-1665) en de wiskundige architectuurwetenschap. Groningen: Philip Elchers.

Goudeau, Jeroen. 2015. The Matrix Regained: Reflections on the Use of the Grid in the Architectural Theories of Nicolaus Goldmann and Jean-Nicolas-Louis Durand. Architectural Histories 3 (1): 1-17. DOI: https://doi.org/10.5334/ah.cl

Günther, Hubertus. 1995. Leitende Bautypen in der Planung der Peterskirche. In L'eglise dans l'architecture de la Renaissance, ed. Jean Guillaume, 41-78. Paris: Picard.

Hubert, Hans W. 2014. Freihand-, Raster-, Schauzeichnung. Bramantes Entwurfsmethodik. Paper presented 4 October 2014 at the Convegno internazionale su Bramante "Inventor e luce della buona e vera Architettura": Bramante e gli "ordini nuovi" nell'architettura del Cinquecento e oltre (2-4 October 2014, Accademia di S. Luca, Rome). Available on YouTube, https://www.youtube.com/ watch?v=zq4HtOmbj-0.

Jobst, Christoph and Kleefisch-Jobst, Ursula. 1994. Cesare Cesariano. Vitruvius. De Architectura libri decem. In Rinascimento da Brunelleschi a Michelangelo. La rappresentazione dell'architettura, eds. Henry A. Millon, Vittorio Magnago Lampugnani. Milano: Bompiani.

Krautheimer, Richard. 1965. Early Christian and Byzantine Architecture. Harmondsworth: Penguin

Laseau, Paul and Tice, James. 1992. Frank Lloyd Wright: Between Principles and Form. New York: Van Nostrand Reinhold.

Niebaum, Jens. 2009. Filarete's Designs for Centrally Planned Churches in Milan and Sforzinda. Arte Lombarda 155 (1): 121-138.

Ottenheym, Konrad. 2014. Proportional Design Systems in Seventeenth-Century Holland. Architectural Histories, 2 (1): 1-14. DOI: https://doi.org/10.5334/ah.bj

Pérez-Gómez, Alberto. 1983. Architecture and the Crisis of Modern Science. Cambridge: The MIT Press

Pérez-Gómez, Alberto. 2016. Filarete's Sforzinda: The Ideal City as a Poetic and Rhetorical Construction. In Chora Seven: Intervals in the Philosophy of Architecture, eds. Alberto Pérez-Gómez and Stephen Parcell. Montreal: McGill-Queen's University Press.

Picon, Antoine. 2000. From "Poetry of Art" to Method: The Theory of Jean-Nicolas-Louis Durand. In Jean-Nicolas-Louis Durand, Précis of the Lectures on Architecture. Los Angeles: The Getty Research Institute. 
Purves, Alexander. 1982. The Persistence of Formal Patterns. Perspecta 19: 138-163.

Ray, Stefano. 1984. Il volo di Icaro. Raffaello architettura e cultura. In Raffaello architetto,eds. Christoph L. Frommel, Stefano Ray and Manfredo Tafuri. Milano: Electa.

Rowe, Colin. 1947. The Mathematics of the Ideal Villa: Palladio and Le Corbusier compared. The Architectural Review 101: 101-104. https://www.architectural-review.com/archive/the-mathematic s-of-the-ideal-villa-palladio-and-le-corbusier-compared, accessed 6 Sept 2020.

Sturm, Leonhard Christoph. 1696. Nicolai Goldmanns vollständige Anweisung zu der Civil-Bau-Kunst. Wolfenbüttel: C.J. Bißmarck.

Thompson, D'Arcy. 1917. On Growth and Form. Cambridge: Cambridge University Press.

Vittone, Bernardo. 1760. Istruzioni elementari per indirizzo de' giovani allo studio dell'architettura civile: divise in libri tre. Lugano: presso gli Agnelli.

Vittone, Bernardo. 1766. Istruzioni diverse Istruzioni diverse concernenti l'officio dell'architetto civile. Lugano: per gli Agnelli e Comp.

Wittkower, Rudolf. 1944. Principles of Palladio's Architecture. Journal of the Warburg and Courtauld Institutes 7: 102-122.

Publisher's Note Springer Nature remains neutral with regard to jurisdictional claims in published maps and institutional affiliations.

Fabio Colonnese is an architect, draftsman and Ph.D. in Drawing and Survey of Architectural Heritage at Sapienza University of Rome, Italy, where he taught Descriptive Geometry, Architecture Survey, and Architecture Drawing. He took part to major survey campaigns, such as Castel Sant'Angelo, the Royal Palace of Caserta and several Rupestrian Monasteries in Cappadocia, Turkey. His Ph.D. research on the labyrinth and its manifold relationships with art, architecture, and city was published in Il Labirinto e l'Architetto (2006). While attending his Rome post-doc fellowship in Digital Survey and Representation of City, he focused on the relationship between the multisensorial experience of space and the image of architecture, as can be read in his book Movimento Percorsi Rappresentazione (2012). In the latest years, his articles and papers have focused mainly on perspective illusory devices in Baroque architecture, digital reconstruction after literary architectures, and architecture modeling. 